\title{
MODIFIKASI GENSET BERBAHAN BAKAR HYBRID DI PILOTPLANT DME BERBAH
}

\author{
Muhrom Khudhori \\ Jurusan Teknik Mesin Sekolah Tinggi Teknologi Adisutjipto \\ Jl Janti Blok R Lanud Adisutipto Yogyakarta \\ muhrom_tm@yahoo.co.id
}

\section{ABSTRACT}

Genset modified with biogas, when biogas empty genset can't used gasoline. Beside that, when genset operated with biogas are corrosion at fuel system, because in the biogas are water steam. So to solution this problems must to research modifications genset with hybrid fuel (biogas-gasoline).

A research with modified on carburetor to assembly venturi mixer. Step $a$ research are engineering design, manufacturing design, and performances test genset modified. Performance parameters are power (watt), voltage (volt), frequency $(\mathrm{Hz})$ and current (ampere).

The conclusion of the research are the genset can operate with carburetor modified, and optimum performances at throttle open $25 \%$. On load 0 the result are voltage 212 Volt, frequency $50,9 \mathrm{~Hz}$, current 0,01 A, power 0 watt, with 800 result voltage 196 Volt, frequency $31,5 \mathrm{~Hz}$, current 2,89 A, power 594 watt. Optimum 700 watt with result voltage 217 volt, frequency $44,3 \mathrm{~Hz}$, current 3,09 A, power 694 watt.

Keywords : Biogas, Hybrid, Generator, Carburetor.

\section{Pendahuluan}

Menipisnya cadangan bahan bakar fosil (BBM), meningkatkan Efek Gas Rumak Kaca (EGRK) mendorong pemerintah mencari sumber energi alternatif sebagai bahan bakar untuk subtitusi/pengganti BBM. Sesuai dengan skenario optimalisasi energi mix nasional 2025 konsumsi bahan bakar ; batu bara (32,7\%), gas bumi $(30,6 \%)$, minyak bumi $(26,2 \%)$, panas bumi $(3,8 \%)$, PLTA $(2,4 \%)$ dan yang lainnya 4,4\% (PLTMH 0,216\%, Biofuel $1,335 \%$, tenaga surya $0,020 \%$, tenaga angin $0,028 \%$, fuel cell $0,000 \%$, biomassa $0,766 \%$, nuklir 1,993\%). Sementara itu kondisi tanah pertanian yang semakin tandus dikarenakan penggunaan pupuk kimia mendesak pemerintah untuk mendorong masyarakat petani menggunakan pupuk organik. Sehingga saat ini perlunya dikembangkan konsep pertanian terpadu dengan prinsip " Zero Waste "(Anonymous, 2006). 
Sehubungan dengan itu, pemerintah telah mendorong program Desa Mandiri Energi (DME) di wilayah Indonesia yang terdapat potensi energi alternatif untuk dikembangkan. DME ini dikembangkan dengan konsep pemanfaatan energi setempat khususnya energi terbarukan untuk pemenuhan kebutuhan energi dan kegiatan yang bersifat produktif. Adapun tujuannya adalah untuk meningkatkan produktivitas, kesempatan kerja dan kesejahteraan masyarakat pada umumnya melalui penyediaan energi terbarukan yang terjangkau dan berkelanjutan(Anonymous, 2009 dan Anonymous, 2010).

Sesuai dengan road map pengembangan energi terbarukan propinsi DIY target tahun 2025 ; PLTS 3000 KWp, PLTMH 750 KW (25 unit terpasang), PLTAngin $160 \mathrm{KW}$, biogas 5000 unit terpasang, biodiesel 1,5\% konsumsi solar dan Desa Mandiri Energi (DME) 10 desa. Dan sesuai dengan rencana umum energi daerah (RUED) propisni DIY kecamatan Berbah merupakan salah satu wilayah yang potensi untuk pengembangan biomassa (biogas) sebagai sumber energi alternatif (Anonymous, 2010).

Di wilayah kecamatan Berbah kabupaten Sleman dengan potensi sumber daya alam (SDA) yang besar, dibidang perikanan tahun 2010 telah dilakukan pencanangan sebagai kawasan minapolitan, kemudian di bidang pertanian sebagai penghasil jagung terbesar di sleman dan di bidang peternakan (sapi) nomer 2 di kabupaten sleman setelah kecamatan Prambanan setelah adanya erupsi Merapi 2010 ini (2083 ekor sapi, kapasitas 3421 ekor sapi) sangat potensi untuk dikembangkan menjadi DME untuk mendukung pembangunan pertanian terpadu dengan prinsip "zero waste “(Khudori, 2010).

Di kelompok kandang Lembu Makmur Di dusun Blendangan desa Tegaltirto kecamatan Berbah (102 ekor sapi, kapasitas 184 ekor sapi) yang menjadi pilot plant DME (Desa Mandiri Energi) saat ini telah memiliki instalasi biogas. Biogas dari hasil instalasi ini selain digunakan untuk memasak (kompor), lampu penerangan (petromax) sebagian digunakan untuk menghidupkan Genset guna penerangan dimalam hari di kandang kelompok untuk menggantikan bensin sebagai bahan bakar genset.

Akan tetapi dengan digunakannya biogas sebagai bahan bakar genset, tentu saja genset tersebut sudah di rancang (dimodifikasi) dengan berbahan bakar gas (biogas) sehingga pada saat biogas habis, genset tersebut tidak dapat dioperasikan menggunakan bensin kembali. Selain itu, pada saat genset dioperasikan menggunakan biogas, pada saluran sistem bahan bakar cepat terjadi korosi (karat) hal ini dikarenakan adanya kandungan uap air 
yang ada di dalam bahan bakar biogas(Khudori, 2011 dan Nugraha, 2011).

Untuk mencari pemecahan permasalahan tersebut, maka perlu dilakukan penelitian tentang perancangan (modifikasi) genset dengan berbahan bakar hybrid (biogas-bensin). Sehingga genset tersebut dapat menggunakan bahan bakar biogas, bahan bakar bensin serta campuran antara biogas dengan bensin (hybrid), sehingga permasalahan genset yang tidak dapat digunakan apabila biogas habis dan cepatnya terjadi korosi pada saluran sistem bahan bakar dapat di cegah (dihindari).

\section{Metode Penelitian}

Penelitian ini menggunakan metode eksperimental dengan langkah-langkah penelitian sebagai berikut.

\section{a. Tahap persiapan}

Sebelum melakukan modifikasi, halhal yang perlu diperhatikan adalah melakukan persiapan alat dan bahan yang akan digunakan meliputi : genset daya 1000 Watt, karburator untuk mesin genset daya 1000 Watt, instrumen pengujian genset, jangka sorong, ragum, gergaji besi, mesin bubut, gerinda listrik, serta memastikan semua dalam keadaan baik.

\section{b. Studi literatur dan observasi}

Dalam studi literatur ini, kita melakukan kajian secara teoritis tentang modifikasi genset berbahan bakar hybrid(biogas + bensin) sebagai bahan bakar. Studi literatur dilakukan dengan mencari informasi dari buku-buku, jurnal, laporan akhir penelitian, skripsi, tesis dan artikel di internet. Dengan melakukan studi literatur ini akan diperoleh informasi berkenaan dengan permasalahan modifikasi genset berbahan bakar hybrid (biogas + bensin).

Selain melakukan studi literatur juga melakukan observasi di lapangan, yaitu observasi pada instalasi biogas di kelompok kandang sapi Blendengan Tegaltirto Berbah untuk mengetahui permasalahan yang ada di kelompok kandang.

Selain itu observasi juga dilakukan di PT. Yanmar divisi penjualan di Kalasan untuk mengetahui kondisi di lapangan tentang ketersediaan genset dengan bahan bakar bensin dan biogas.

\section{c. Desain enjiniring, Desain \\ Manufakturing dan Assembly \\ Desain enjiniring adalah melakukan} perancangan secara teknis berkaitan dengan modifikasi karburator genset daya 1000 Watt. Yang dilakukan dalam tahap ini meliputi ; pembelahan karburator, pembersihan, pengukuran bagian karburator, membuat gambar konsep dan rancangan dasar, meliputi: kajian dan penggambaran sistem bahan bakar (karburator), melakukan perhitungan komponen karburator, melakukan perhitungan kebutuhan jumlah campuran 
bahan bakar (bensin) dengan udara yang masuk ke ruang bakar, melakukan perhitungan kebutuhan jumlah campuran bahan bakar (biogas+bensin) dengan udara yang masuk ke ruang bakar dan membuat gambar enjiniring rancangan karburator hasil modifikasi.

Desain manufakturing adalah perancangan cara pembuatan komponen hasil modifikasi berdasarkan dari desain enjiniring. Hal-hal yang dilakukan dalam desain manufacturing ini meliputi ; melakukan pembubutan, melakukan pemotongan, membuat alur drat, melakukan pengeboran dan melakukan pengelasan.

Assembly adalah kegiatan perakitan komponen-komponen hasil modifikasi untuk mendapatkan karburator hasil modifikasi yang akan dipasang pada genset yang berbahan bakar hybrid (biogas + bensin). Setelah semua dirakit dan dipasang pada mesin genset, maka selanjutnya dilakukan uji coba.

\section{d. Pelaksanaan Pengujian Unjuk Kerja Genset}

Pengujian unjuk kerja genset dilakukan pada kondisi standar (menggunakan bahan bakar bensin) dan pada kondisi sudah dimodifikasi (berbahan bakar biogas+bensin). Pada setiap pengujian, hal yang akan dilakukan pengukuran dan pencatatan meliputi :

a. Beban Lampu (Watt)
b. Tegangan (V)
c. Arus (I)
d. Bukaan Throttle (\%)

\section{Analisis Data}

Data yang diperoleh dari hasil pengujian unjuk kerja genset kemudian dilakukan interpretasi data. Kemudian dibuat grafik agar mempermudah dalam analisis data.

\section{Hasil dan Pembahasan}

a. Hasil Penelitian

a. Desain enjiniring

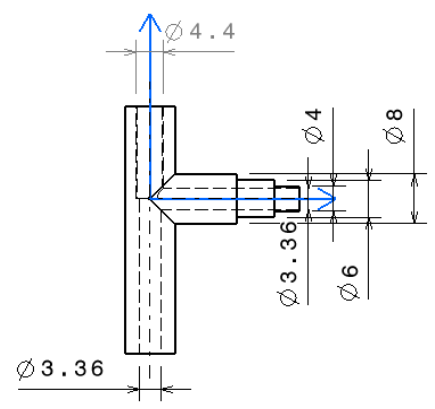

\section{Gambar 1. Desain Venturi Mixer}

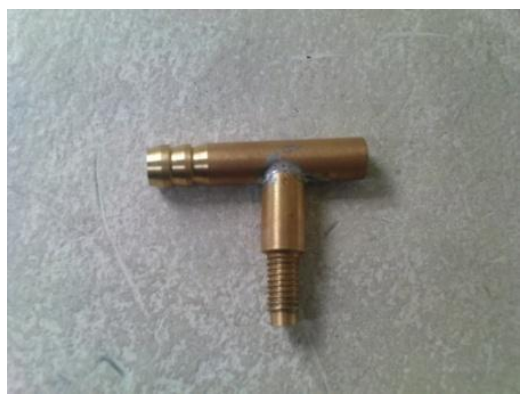

Gambar 2. Venturi Mixer 
b. Prototipe Karburator

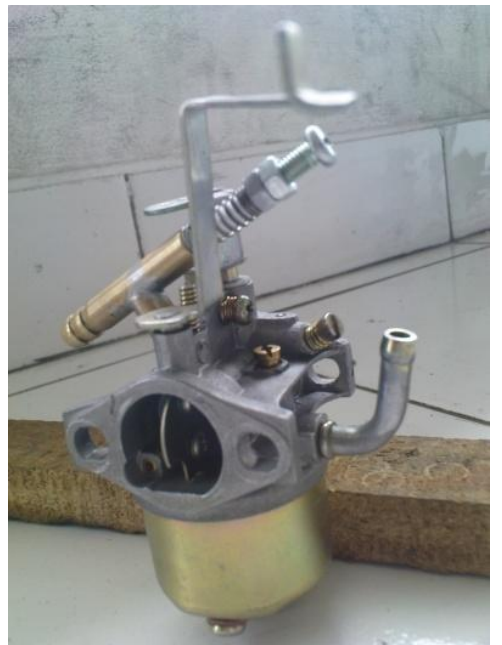

Gambar 3. Prototipe Karburator Modifikasi

c. Unjuk kerja genset

Hasil pengujian unjuk kerja genset hasil modifikasi diberikan pada grafik dibawah ini:

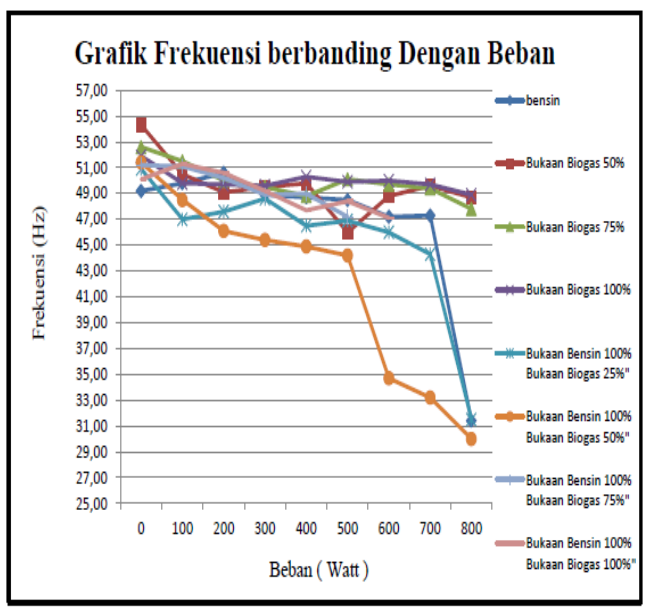

Gambar 4. Hubungan Frekuensi terhadap Beban

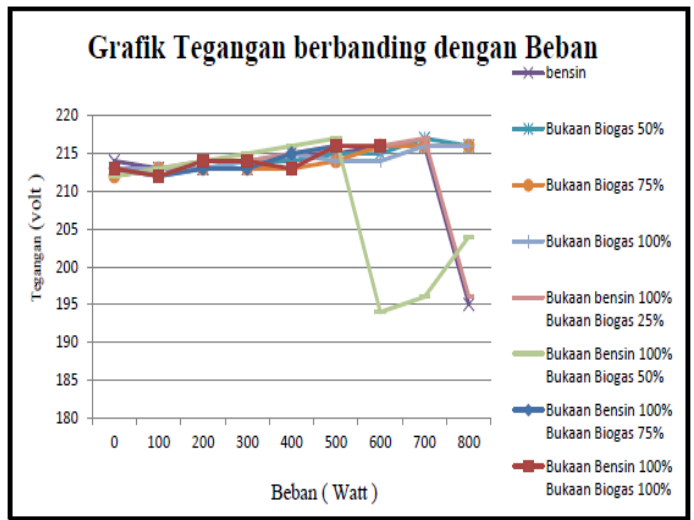

Gambar 5. Hubungan Tegangan terhadap Beban

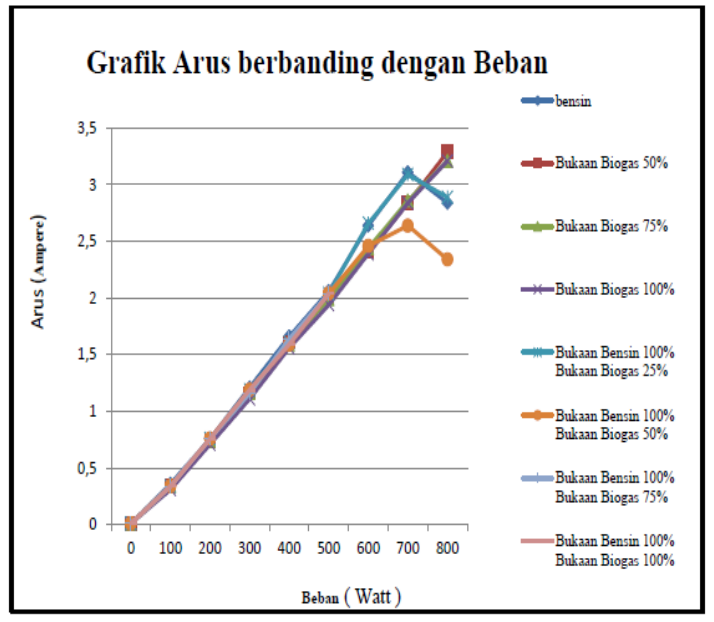

\section{Gambar 6. Hubungan Arus terhadap} Beban

\section{b. Pembahasan}

Penggunaan campuran bahan bakar bensin + biogas secara bersama-sama (hybrid) pada genset 1000 Watt yang semula di rancang dengan bahan bakar bensin diperlukan perubahan pada sistem bahan bakar. Karburator yang merupakan komponen sistem bahan bakar yang berfungsi untuk mengatur jumlah dan pencampuran bahan bakar yang 
memungkinkan untuk dilakukan jumlah bahan bakar bensin dan biogas modifikasi.

Dalam memodifikasi karburator yang mengalir masuk ke ruang bakar pada pembukaan throttle yang sama.

untuk diganti dengan berbahan bakar Daya genset yang paling optimum hybrid perlu menambahkan venturi mixer yang diletakkan pada bagian dari karburator. Saluran asli dipergunakan untuk bahan bakar bensin, sedangkan venturi mixer untuk mengalirkan biogas yang akan menuju ke ruang bakar. Penentuan besarnya diameter saluran venturi tersebut tergantung dari jumlah bahan bakar biogas yang akan dimasukkan, dalam hal ini sesuai dengan besarnya daya genset, semakin besar daya genset maka diameter lubang saluran venturi mixer juga semakin besar.

Besarnya jumlah bahan bakar (bensin+biogas) yang masuk ke dalam ruang bakar tergantung dari besarnya kevakuman yang terdapat dalam ruang bakar berdasarkan pembukaan throttle. Semakin besar pembukaan throttle, maka jumlah bahan bakar yang mengalir masuk ke ruang bakar juga banyak, demikian juga sebaliknya. Sifat dan karakteristik bahan bakar akan mempengaruhi kemampuan merespon terhadap perubahan tekanan (kevakuman). Kemampuan merespon perubahan tekanan bahan bakar cair (bensin) berbeda dengan bahan bakar gas (biogas), bensin bersifat inkompresibel sedangkan biogas adalah kompresibel. Dan hal ini yang mempengaruhi perbedaan diperoleh pada pembukaan throttle $25 \%$. Pada pembukaan yang lebih besar, jumlah bahan bakar biogas yang mengalir tidak sebanding dengan jumlah bensin, sifat kompresibel biogas mempengaruhi responsivitas biogas terhadap adanya perubahan tekanan dalam ruang bakar, hal inilah yang menjadi penyebab terjadinya perbedaan jumlah bensin dan biogas yang mempengaruhi jumlah koposisi campuran bahan bakar.

Penyebab lain terjadinya penurunan daya pada putaran yang lebih tinggi adalah karena saluran venturi mixer yang dibuat tidak dapat dirubah (fixed). Sehingga pada saat putaran rendah, jumlah biogas banyak (kurang udara) sedangkan pada putaran tinggi kekurangan biogas (kelebihan udara), sehingga menyebabkan pembakaran tidak sempuna. Agar jumlah biogas yang mengalir sesuai dengan kebutuhan (tingkat kevakuman) maka diperlukan venturi mixer yang flexible, artinya dapat mengalirkan biogas sesuai dengan kebutuhan.

\section{KESIMPULAN}

Dari hasil modifikasi karburator yang telah dilakukan didapatkan ukuran venturi mixer untuk bahan bakar biogas 
menggunakan pipa kuningan dengan panjang $40 \mathrm{~mm}$ berdiameter $8 \mathrm{~mm}$ dengan lubang (diameter dalam) 3,36 $\mathrm{mm}$ dan panjang $24 \mathrm{~mm}$ dengan diameter $8 \mathrm{~mm}, 5$ $\mathrm{mm}, 4 \mathrm{~mm}$ yang bertangga, geometri saluran udara masuk $21 \mathrm{~mm}$, diameter saluran keluar $16 \mathrm{~mm}$, diameter venturi 10 $\mathrm{mm}$.

Genset dapat hidup pada saat menggunakan karburator hasil modifikasi. Pengujian genset tipe GX 154 YASUKA dengan bahan bakar dual - fuel mendapatkan hasil terbaik dengan pembukaan $25 \%$ putaran kran regulator pada tabung biogas menghasilkan data sebagai berikut. Pada beban 0 dihasilkan tegangan 212 Volt, frekuensi sebesar 50,9 $\mathrm{Hz}$, arus $0,01 \mathrm{~A}$, daya 0 watt sedangkan dengan beban 800 dihasilkan tegangan 196 Volt, frekuensi 31,5 Hz, Arus 2,89 A, daya 594 watt. Beban paling ideal pada beban 700 watt dengan hasil tegangan 217 volt, frekuensi 44,3 Hz, Arus 3,09 A, daya 694 watt.

Unjuk kerja modifikasi mesin Genset tipe GX 154 YASUKA dengan bahan bakar dual fuel ( biogas dan bensin ) hasilnya kerja yang dihasilkan dari genset lebih stabil dibanding hanya dengan bensin saja. Terutama pada saat pembukaan $25 \%$ putaran kran regulator.

\section{SARAN}

Berdasarkan pengamatan pada saat pengujian masih mengalami kesulitan dalam menghidupkan genset, hal ini dikarenakan udara yang masuk kedalam saluran masuk mengalami kekurangan, sedangkan pada saat percepatan mengalami kekurangan bahan bakar (biogas). Untuk itu disarankan untuk dilakukan penelitian lanjut untuk mendapatkan putaran yang stabil pada berbagai variasi kecepatan dengan menggunakan regulator sebagai pengatur aliran bahan bakar (biogas) yang masuk ke dalam ruang bakar.

\section{UCAPAN TERIMA KASIH}

Terima kasih kepada DITLITABMAS Dirjen Dikti di Jakarta yang telah mendanai penelitian ini melalui Hibah Penelitian Dosen Pemula Bagi Dosen Perguruan Tinggi Swasta Tahun Anggaran 2012 Nomor : 286/SP2H/PL/Dit. Litabmas/VI/2012 Tanggal 15 Juni 2012.

\section{DAFTAR PUSTAKA}

Anonymous, 2006. " Blue Print Pengelolan Energi Nasional 20052025 “, ESDM, Jakarta.

Anonymous. 2009." Profil Pengembangan Bio-Energi Perdesaan (Biogas) ", Departemen Pertanian, Jakarta.

$\begin{array}{cc}\text { Anonymous.2010." Pedoman } & \text { Teknis } \\ \text { Pengembangan } & \text { Usaha }\end{array}$


Pengolahan Kompos Dan Biogas

", Kementerian Pertanian, Jakarta.

Anonymous. 2010." Rencana Umum

Energi Daerah (RUED) Propinsi $D I Y$ ", Dinas PUP-ESDM Propinsi DIY, Yogyakarta.

Khudhori M. 2010. " Konsep Pertanian Terpadu Dengan Prinsip “ Zero Waste" Pilot Project DME Di Kelompok Kandang Berbah ", Paguyuban Peduli Sleman (PPS), Yogyakarta.

Khudhori, M. 2011. Desain Modifikasi Karburator Dengan Penambahan Venturi Mixer Tipe Nozzle Pada Mesin Bensin Penggerak APPO Berbahan Bakar Biogas Daya 6,5 HP Untuk Mendukung Konsep Pertanian Terpadu (Zero Waste) Di Pilot Plant DME (Desa Mandiri Energi) Berbah, Laporan Penelitian Kopertis V Tahun 2011.

Nugraha S.A., 2011.” Modifikasi Karburator Genset Bahan Bakar Bensin Menjadi Bahan Bakar Biogas atau Bensin (Hybrid) Pada Mesin Bensin 4 Langkah Tipe GX 154 Yasuka”. Skripsi S-1, Jurusan Teknik Mesin STTA, Yogyakarta, tidak dipublikasikan.

Mitzlaff K.V. 1988. " Engine For Biogas ", GTZ. Africa.

Pulkrabek W.W., 2004. "Engineering Fundamental of the Internal combustion Engine", Prentice Hall., Wisconsin. 